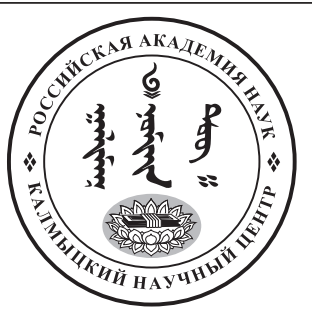

Published in the Russian Federation

Oriental Studies (Previous Name: Bulletin of the Kalmyk Institute

for Humanities of the Russian Academy of Sciences)

Has been issued as a journal since 2008

ISSN: 2619-0990; E-ISSN: 2619-1008

Vol. 13, Is. 6, pp. 1594-1612, 2020

DOI: $10.22162 / 2619-0990-2020-52-6-1594-1612$

Journal homepage: https://kigiran.elpub.ru

УДК $903.2(470.57)$

DOI: $10.22162 / 2619-0990-2020-52-6-1594-1612$

\title{
Стоянка-мастерская Кусимово-6 - памятник эпохи среднего палеолита в Южном Зауралье
}

\section{Вячеслав Георгиевич Котов ${ }^{1}$, Никита Сергеевич Савельев ${ }^{2}$, Рида Раисовна Русланова ${ }^{3}$}

${ }^{1}$ Институт истории, языка и литературы Уфимского федерального исследовательского центра РАН (д. 71, пр. Октября, 450054 Уфа, Российская Федерация) кандидат исторических наук, старший научный сотрудник iD 0000-0002-3510-0058. E-mail: slav1@yandex.ru

${ }^{2}$ Институт истории, языка и литературы Уфимского федерального исследовательского центра РАН (д. 71, пр. Октября, 450054 Уфа, Российская Федерация) кандидат исторических наук, ведущий научный сотрудник iD 0000-0002-3643-2388. E-mail: sns_1971@mail.ru

${ }^{3}$ Объединенный Национальный музей Республики Башкортостан (д. 14, ул. Советская, 450077 Уфа, Российская Федерация) кандидат исторических наук, заведующий отделом iD 0000-0003-3929-9516. E-mail: ridushka@mail.ru

(C) КалмНЦ РАН, 2020

(С) Котов В. Г., Савельев Н. С., Русланова Р. Р., 2020

Аннотация. В 2019 г. была открыта и исследована на большой площади стоянка-мастерская Кусимово-6 в Абзелиловском районе Республики Башкортостан. Была получена большая коллекция изделий среднего палеолита - более 2 тысяч находок. Анализ коллекции показал ее гомогенность. Нуклеусы представлены подпризматическими, с продольным скалыванием, ортогональными, радиальными и бессистемными типами. Многие ядрища имеют две и больше плоскостей скалывания. Треть сколов имеет естественные ударные площадки и спинку. Обработка бифациальных орудий в основных чертах повторяет характер обработки нуклеусов. Среди этих орудий представлены рубило, 2 заготовки бифасов, 2 остроконечника, одно острие, обушковые ножи. Двусторонней обработкой оформлялись рабочие участки и у других категорий орудий (резчиков, проколок, острий, орудий с шипом, клювовидных, выемчатых орудий, скребков). Памятник по всем признакам имеет нелеваллуазкий характер и относится к индустрии тейякской традиции среднего палеолита. Наибольшее сходство стоянка-мастерская Кусимово-6 обнаруживает с III и IV слоями с тейякской индустрией среднего палеолита грота Старые Дуруиторы на северо-западе Молдовы. Соответственно, стоянка Кусимово-6 может датироваться первой половиной рисского времени (300-200 тыс. лет назад). 
Ключевые слова: средний палеолит, тейякская традиция, технология, типология, Южное Зауралье, Восточная Европа

Благодарность. Исследование проведено в рамках государственной субсидии проект «Духовная культура тюркских народов Южного Урала» (номер госрегистрации: AAAA-A17-117040350082-3).

Для цитирования: Котов В. Г., Савельев Н. С., Русланова Р. Р. Стоянка-мастерская Кусимово-6 - памятник эпохи среднего палеолита в Южном Зауралье // Oriental Studies. 2020. Т. 13. № 6. C. 1594-1612. DOI: 10.22162/2619-0990-2020-52-6-1594-1612

UDC $903.2(470.57)$

DOI: $10.22162 / 2619-0990-2020-52-6-1594-1612$

\title{
Workshop Site of Kusimovo-6 - a Middle Paleolithic Monument in the Southern Transurals
}

\author{
Vyacheslav G. Kotov ${ }^{1}$, Nikita S. Savelev ${ }^{2}$, Rida R. Ruslanova ${ }^{3}$ \\ ${ }^{1}$ Institute of History, Language and Literature of the Ufa Federal Research Centre of the RAS \\ (71, Oktyabrya Ave., Ufa 450054, Russian Federation) \\ Cand. Sc. (History), Senior Research Associate \\ iD 00001-0002-3510-0058. E-mail:kslav1@yandex.ru
}

${ }^{2}$ Institute of History, Language and Literature of the Ufa Federal Research Centre of the RAS (71, Oktyabrya Ave., Ufa 450054, Russian Federation) Cand. Sc. (History), Leading Research Associate iD 0000-0002-3643-2388. E-mail: sns_1971@mail.ru

${ }^{3}$ National Museum of Bashkortostan (14, Sovetskaya St., Ufa 450077, Russian Federation) Cand. Sc. (History), Head of Department

iD 0000-0003-3929-9516. E-mail: ridushka@mail.ru

(C) KalmSC RAS, 2020

(C) Kotov V. G., Saveliev N. S., Ruslanova R. R., 2020

\begin{abstract}
In 2019, the workshop site of Kusimovo-6 in Abzelilovsky District of Bashkortostan (Russia) was discovered and explored on a large area. A collection of Middle Paleolithic artifacts numbering over 2 thousand was obtained. Goals. The work attempts at an analysis of the collection. Results. The latter shows its homogeneity. So, nucleuses are subprismatic, with longitudinal cleavages, orthogonal, radial, and of unsystematic types. Many cores have two or more strike platforms. A third of the flakes have natural strike platforms and backrest. The producing of bifacial tools basically repeats the nucleuses' production patterns. The tools comprise a chopper, 2 blanks of bifaces, 2 taiyak points, a point, butt knives. Two-sided producing was performed on working areas of other categories of tools (carvers, punctures, points, tools with a spike, beak-shaped, notched tools, scrapers). By all indications, the site has a non-Levallois character and belongs to the industry of the Tayacian tradition of the Middle Paleolithic. The workshop site of Kusimovo-6 reveals the greatest similarity with the $3^{\text {rd }}$ and $4^{\text {th }}$ layers (Tayacian industry of the Middle Paleolithic) of the Starye Duruitory Grotto in Northwest Moldova. Accordingly, the workshop site of Kusimovo-6 is dated to the first half of the Rissian period (300-200 thousand years ago).

Keywords: Middle Paleolithic, Tayacian tradition, technology, typology, Southern Transurals

Acknowledgements. The reported study was funded by government subsidy — project name 'Turkic Peoples of the Southern Urals: Spiritual Culture' (state reg. no. AAAA-A17-117040350082-3).

For citation: Kotov V. G., Savelev N. S., Ruslanova R. R. Workshop Site of Kusimovo-6 - a Middle Paleolithic Monument in the Southern Transurals. Oriental Studies. 2020. Vol. 13(6): 1594-1612. (In Russ.). DOI: 10.22162/2619-0990-2020-52-6-1594-1612
\end{abstract}




\section{Введение}

Палеолит уральского региона изучен еще далеко недостаточно. Прежде всего, это касается памятников раннего и среднего палеолита. В этой связи большое значение для понимания процессов заселения и освоения этой территории имеет открытие в Южном Зауралье новой стоянки среднего палеолита с многочисленной коллекцией каменных изделий.

Стоянка находится у восточного подножья хребта Крыктытау, в небольшой долине между двумя хребтиками, открытой на восток к оз. Сабакты, на восточной окраине д. Кусимово Абзелиловского района Башкортостана, в 30 км к востоку от г. Магнитогорска (рис. 1, 2). До современного берега оз. Сабакты - около 1,8 км к востоку, а до известной палеолитической стоянки Мысовая (Карабалыкты VII) - 3,7 км к северо-востоку. Стоянка-мастерская приурочена к небольшому мысовидному возвышению высотой около 5 м посреди долины с размерами 60х160 м (рис. 3).

Курган Кусимово-3 был зафиксирован в 2005 г. в ходе сплошного обследования Курортного района Якты-Куль [Котов 2008]. Палеолитический памятник был выявлен в 2019 г. в ходе раскопок каменного кургана эпохи раннего железа Кусимово-3 (руководитель экспедиции Н. С. Савельев). Поверх кургана был заложен квадратный раскоп с общими размерами $18 \times 18$ м, общая пло-

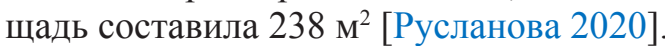

Особенностью отложений является то, что они неоднократно перепахивались на всю глубину гумусированной толщи, с чем было связано перемешивание и перемещение археологического материала. Фрагменты непотревоженного культурного слоя эпохи палеолита небольшими участками сохранились под каменно-земляной насыпью кургана в слое серовато-коричневого легкого суглинка с доломитовой крошкой и слегка окатанной кремневой галькой мощностью до 0,2 м. В трех шурфах вблизи раскопа слой серовато-коричневого легкого суглинка или супеси с доломитовой крошкой залегает под слоем гумуса на глубине 0,5 м. Нижний край этого слоя разбит многочисленными клиньями, уходящими на глубину до 0,5 м вглубь нижележащего желтого суглинка. На поверхности этого слоя залегает слой кремневой гальки. К краю террасы палеоозера Якты-куль-Сабакты слой гальки достигает мощности 1 м и слой серовато-коричневой супеси с доломитовой крошкой превышает 1 м. Наличие многочисленных клиньев, очевидно морозобойного происхождения, указывает на то, что они формировались во время максимума оледенения, завершившегося катастрофическими процессами резкого подъема уровня воды в палеоозере Якты-куль-Сабакты и перемещении больших масс галечного материала и кусков кремнистых пород с вершин близлежащего хребта, где находятся их выходы. Наличие отложений слоя гальки на поверхности мыса говорит о том, что мыс находился в прибойной зоне и в период существования палеолитической стоянки он являлся берегом палеоозера Якты-Куль-Сабакты. Ориентируясь на линии горизонталей, мы предварительно реконструировали границы этого палеоозера (рис. 2).

Сходная ситуация существования древних озер была выявлена и в других местах Южного Урала: на озерах Калкан, Чубтэкуль, Ургун, Талкас, Султанкул, Атавды и Култубан. Геологические исследования Пра-Атавдинской и Пра-Култубанской озерных впадин показали, что озерный режим в них существовал с раннего до первой половины среднего плейстоцена [Казаков 2017: 64; Казаков 2018]. Подтверждением существования праозера Сагылкуль около оз. Култубан (Баймакский район Башкортстана) в среднем плейстоцене являются многочисленные ашельские местонахождения (Карышкино- 11,12 , Долина- 1,11$)$ по берегам этого праозера [Котов 2009: 29; Котов 2015].

\section{Каменный инвентарь}

Все изделия из кремня стоянки-мастерской Кусимово-6 (2 219 экз.) по технико-типологическим характеристикам относятся к одной эпохе, поэтому мы условно считаем стоянку однослойной и всю коллекцию рассматриваем как единый комплекс.

Расположение памятника на выходах кремневого сырья предопределило нали- 


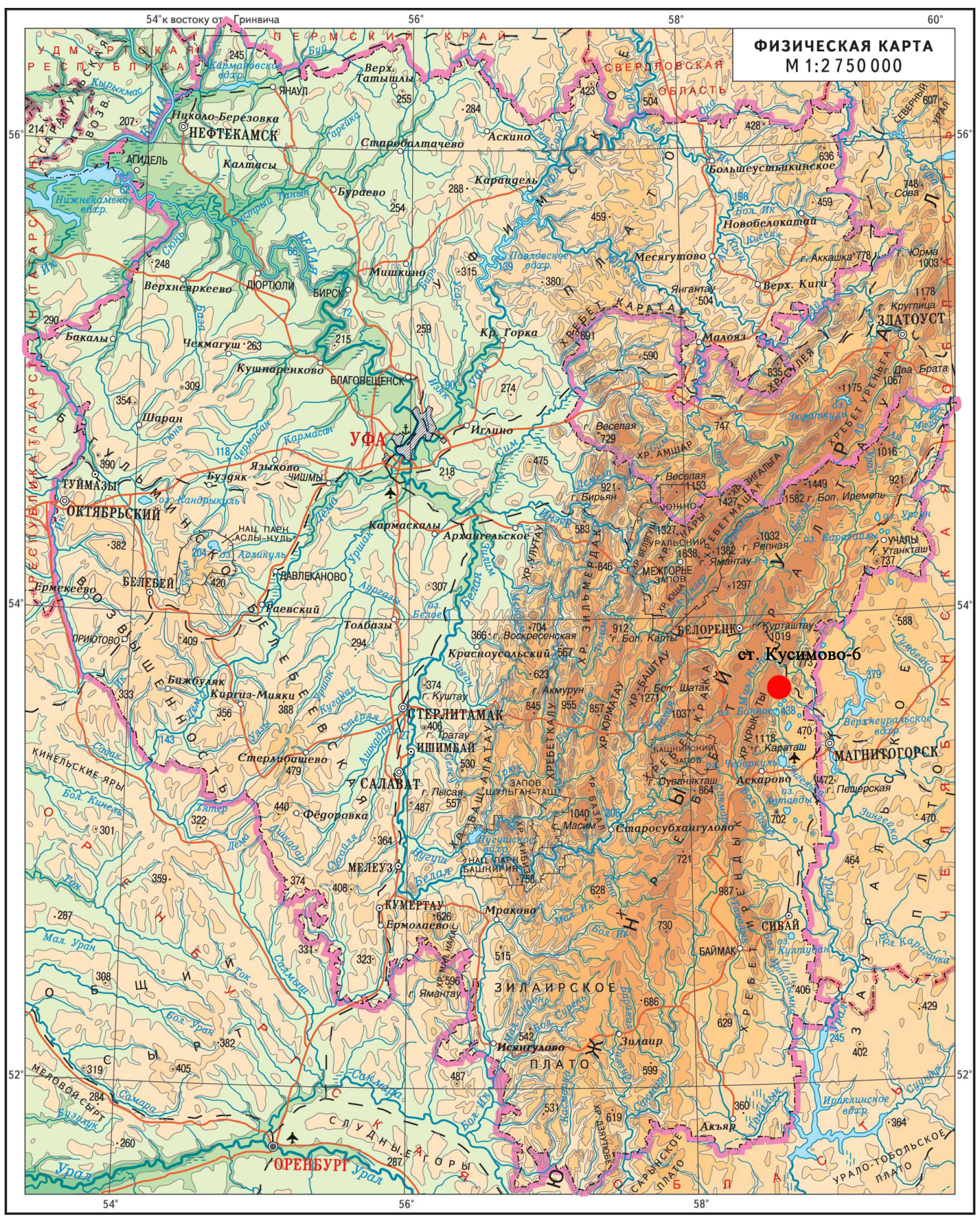

Puc. 1. Местонахождение (отмечено красной точкой) стоянки-мастерской Кусимово-6 на территории Республики Башкортостан-мастерская // Республика Башкортостан: физическая карта. Масштаб: 1: 2750 000. М.: Роскартография, 2013.

[Fig. 1. Location (red dot) of the workshop site of Kusimovo-6 (Bashkortostan, Russia). Physical map of Bashkortostan. Scale 1 : 2750 000. 2013] 


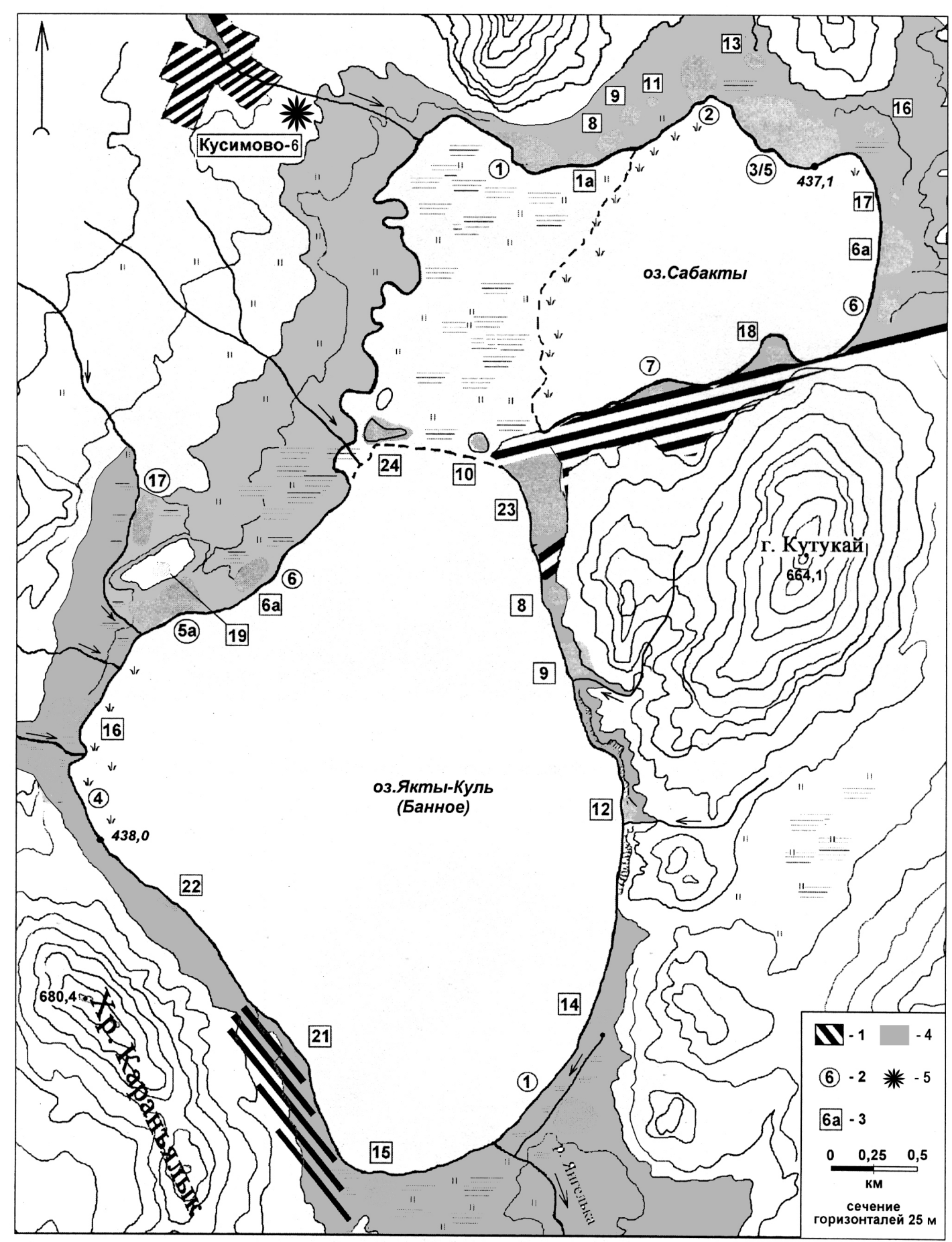

Puc. 2. Карта памятников на территории озер Банное и Сабакты. Условные обозначения: 1 границы поселений, 2 - памятники, известные до 2004 г., 3 - памятники, открытые в 2004 г., 4 границы трансгрессии озера Яктыкуль-Сабакты в древности, 5 - стоянка-мастерская Кусимово-6. Цифрами обозначены номера археологических памятников по берегам озер Банного и Сабакты. Авторы: Н. С. Савельев, В. Г. Котов

[Fig. 2. Map of monuments located within (around) Lakes Bannoe and Sabakty. Legend: 1 — boundaries of settlements, 2 - monuments known before 2004, 3 - monuments discovered in 2004, 4- boundaries of transgression of Lake Yaktykul-Sabakty in ancient times, 5 - workshop site of Kusimovo-6. Figures indicate numbers of archaeological monuments on shores of Lakes Bannoe and Sabakty. Comp. by

N. Savelev and V. Kotov] 


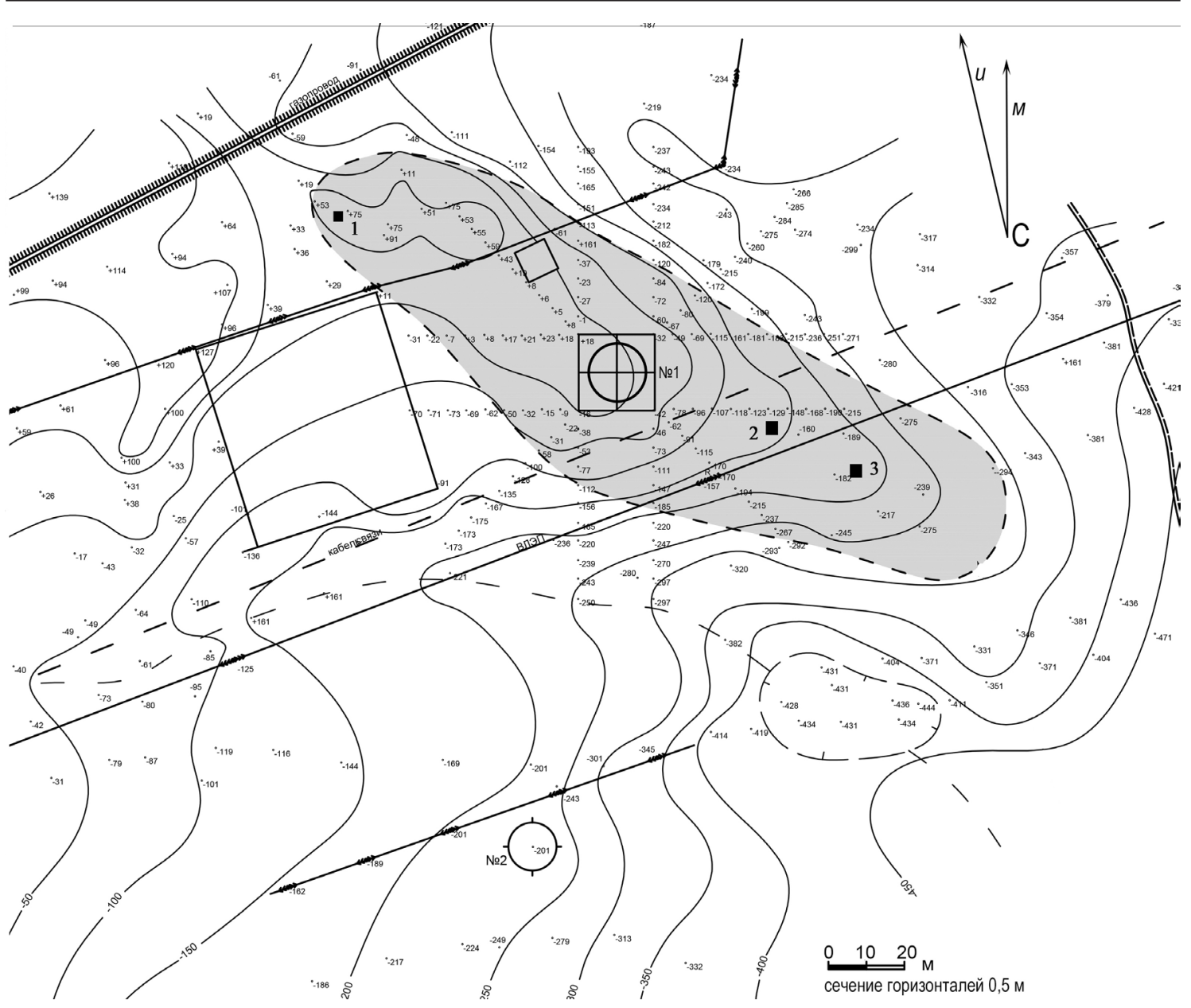

Puc. 3. Ситуационный план стоянки-мастерской Кусимово-6 и курганного могильника Кусимово-3. Черными квадратами с цифрами 1, 2 и 3 обозначены шурфы. № 1 и № 2 - обозначение курганов № 1 и № 2 курганного могильника Кусимово-3. Авторы: Н. С. Савельев, У. О. Коршунова

[Fig. 3. Layout of the workshop site of Kusimovo-6 and Kusimovo-3 mound burial site. Shafts marked with black numbered squares $(1,2,3)$. No. 1 and 2 stand for mounds 1 and 2 of Kusimovo-3 mound burial site, respectively. Comp. by N. Savelev and U. Korshunova] 
чие всего комплекса первичной обработки от опробования сырья до полностью сработанных нуклеусов. В качестве сырья использовались гальки или же куски фтанита кремнистой породы, присутствующей в изобилии в окрестностях, фтаниты имеют различный цвет - от светло-серого до черного, встречается полосчатый окрас [Mосин, Никольский 2008: 41$]$.

Скольл. Интересную информацию предоставляет анализ сколов, которых выявлено 1769 экз. Среди них сколов с естественными ударными площадками - 584 экз. (33\%) и галечной коркой на спинке 630 экз. (35,6 \%). Второй по численности является точечная ударная площадка 305 экз. (17\%). На третьем месте гладкие ударные площадки, созданные одним сколом - 212 экз. (12 \%). За ними по количеству следуют двугранные площадки 106 экз. (6 \%). Важно, что среди площадок имеются грубо фасетированные, то есть состоящие из 3-4 фасеток, которых насчитывается 44 экз. (2,5 \%). Тонко фасетированные ударные площадки единичны. Обращает внимание тот факт, что 388 экз. сколов (22\%) имеют удаленные ударные площадки вместе с ударными бугорками. В большинстве случаев удаление производилось с помощью обломов и только небольшая часть с помощью ретуши и сколов утоньшения (рис. 5: 3, 10, 13; 6: 2, 3, 4, 6, 8, 13). Также было установлено, что у сколов отсутствовала какая-либо связь между характером ударной площадки и огранкой спинки. В коллекции присутствует 6 экз. пластин и 21 экз. пластинчатых отщепов. Большая часть пластин аморфные, и они имеют трехгранное сечение.

Орудия для производства орудий. Все негативы сколов на нуклеусах рельефные с глубокими выемками от ударных бугорков. Это свидетельствует об использовании для расщепления твердых отбойников. В коллекции присутствуют многочисленные отбойники на гальках из кремня (73 экз.) размером от 5 до 10 см длинной (рис. 7: 2). Изредка попадаются отбойники на гальках из диабаза. Небольшую серию (4 экз.) образуют ударные инструменты на гальках удлиненной формы, у которых использовались в качестве рукояток одна половина, в то время как боковые поверхности и дистальный конец употреблялись в качестве молотков для расщепления нуклеусов и обработки бифасов.

Нуклеусы. Памятник отличается большим разнообразием нуклеусов (250 экз.). Небольшой серией (5 экз.) представлены ядрища с плоскостным продольным снятием удлиненных пластинчатых и укороченных сколов первичного и вторичного снятия. Формы нуклеусов могут быть различными, например клиновидная или же конусовидная. Встречаются подчетырехугольные уплощенные формы нуклеусов параллельного скалывания (рис. 4: б). Следует обратить внимание на то, что мастер более мелкими сколами на этом и на ряде других нуклеусов выравнивал поверхность скалывания вблизи края ударной площадки (рис. 4: 1, 7, 8). Часто снятие сколов на нуклеусах производилось с неподготовленных площадок во встречном направлении (рис. 4: 1) или же в плоскостях, перпендикулярных основной плоскости скалывания, - такие нуклеусы были отнесены к ортогональным (15 экз.) (рис. 4: 3, 5). Нередко невозможно отличить ударную площадку от плоскости скалывания заготовок (рис. 4: 7, 8). У многих нуклеусов зафиксировано беспорядочное скалывание отщепов в различных направлениях с многочисленных ударных площадок, которыми становились негативы предшествующих снятий. Такие нуклеусы были отнесены к бессистемным - 41 экз. (рис. 4: 1).

Некоторые нуклеусы имеют две плоскости скалывания, причем на одной плоскости осуществлялось параллельное скалывание удлиненных отщепов, а на другой скалывание имеет радиальный характер.

Нуклеусов с радиальной огранкой 10 экз. (4 \%). Они подразделяются на односторонние и двухсторонние. Односторонние радиальные нуклеусы были получены в процессе раскалывания уплощенной гальки черного кремня, размер: $5,3 \times 5,0 \times 2,8$ см и $8,5 \times 5,5 \times 1,6$ см (рис. 4: 2). Двусторонние радиальные нуклеусы преобладают. Они также были получены в ходе расщепления кремневых галек (рис. 4: 4).

Орудия. Всего в коллекции было выявлено 304 экз. орудий (это без отбойников, молотков и ретушеров). На стоянке-мастерской Кусимово-6 было обнаружено 5 бифасов и 1 бифациальный остроконечник: бифас-рубило на гальке серого кремня 

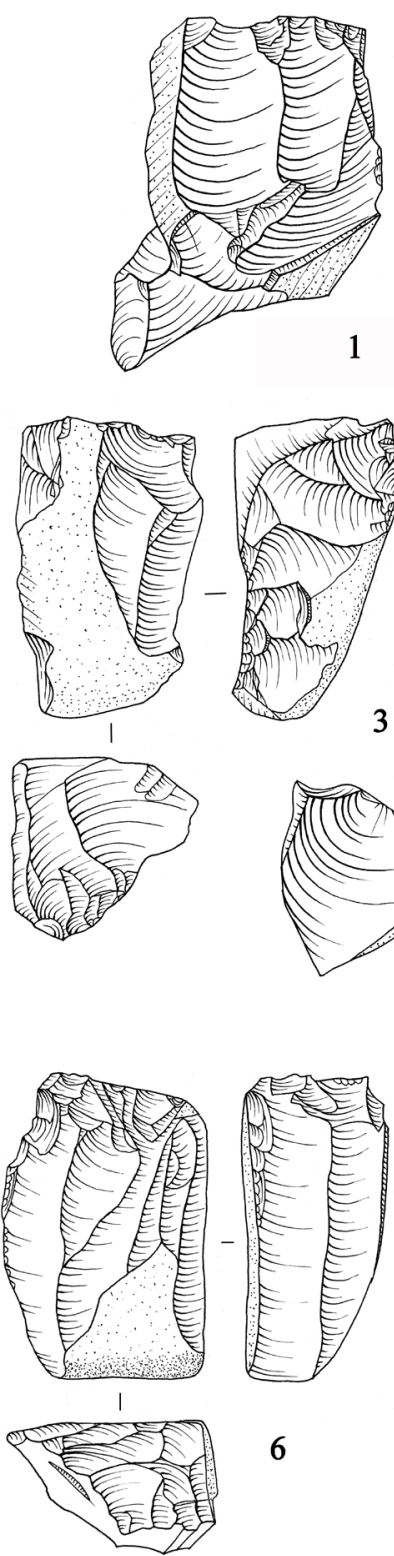

6
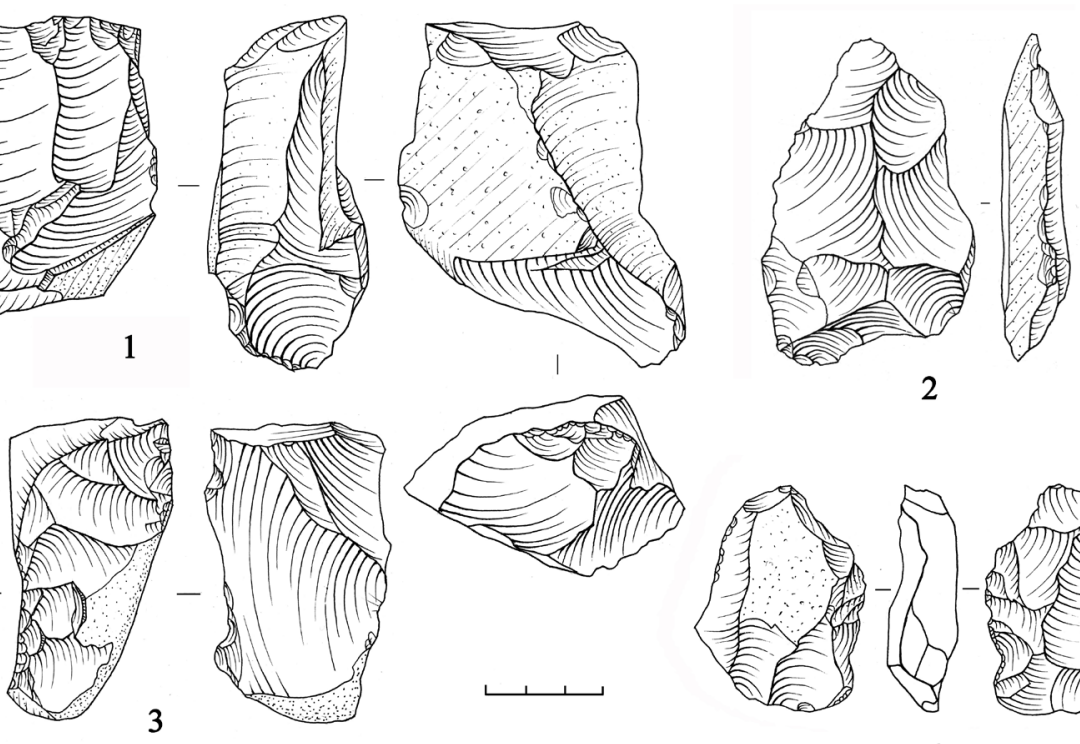

4
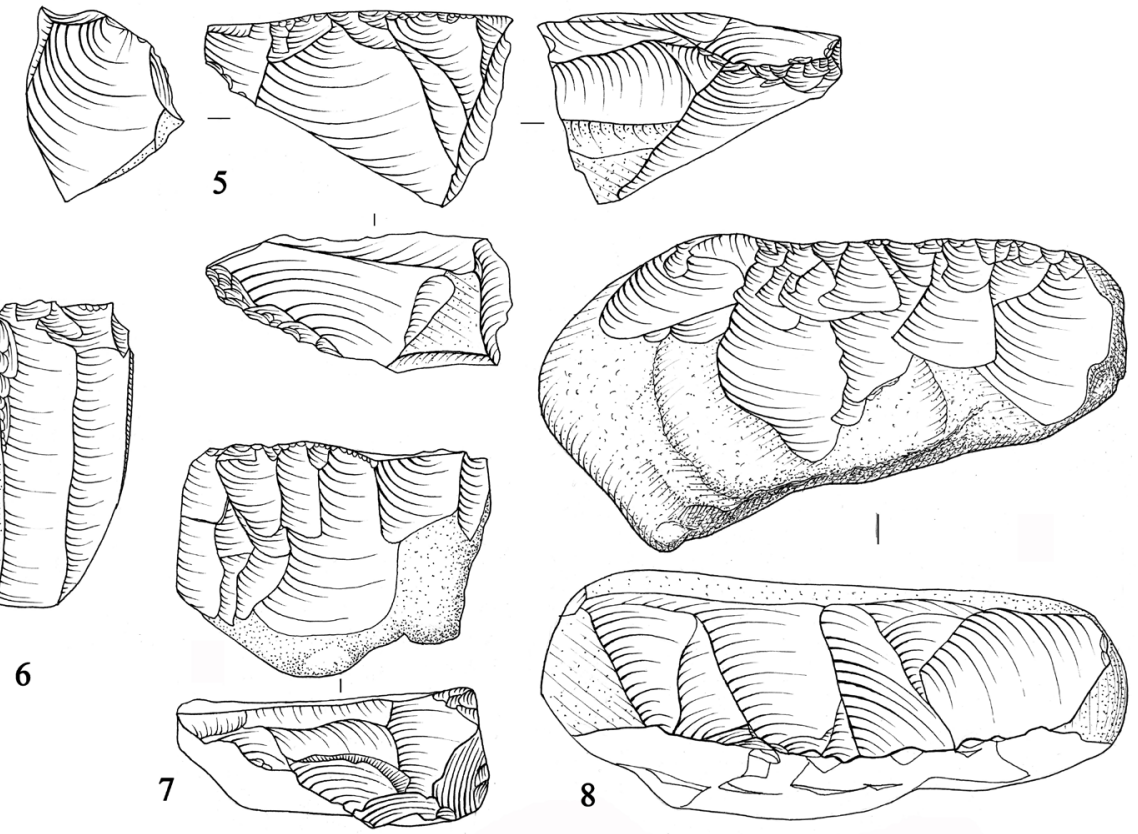

Puc. 4. Стоянка-мастерская Кусимово-6. Нуклеусы: 1 - продольного снятия, 2 - радиальный односторонний, 3 - ортогональный, многоплощадочный, 4 - двусторонний радиальный, 5 ортогональный, 6 - подчетырехугольный параллельного скалывания, 7, 8 - параллельного снятия, одноплощадочные. Кремень. Автор: В. Г. Котов

[Fig. 4. Workshop site of Kusimovo-6. Cores: 1 - longitudinal, 2 - one-sided radial, 3 - orthogonal, multi-platform, 4 - double-sided radial, 5 - orthogonal, 6 - sub-quadrangular parallel, 7, 8 - parallel, single-platform. Flint. Prep. by V. Kotov] 

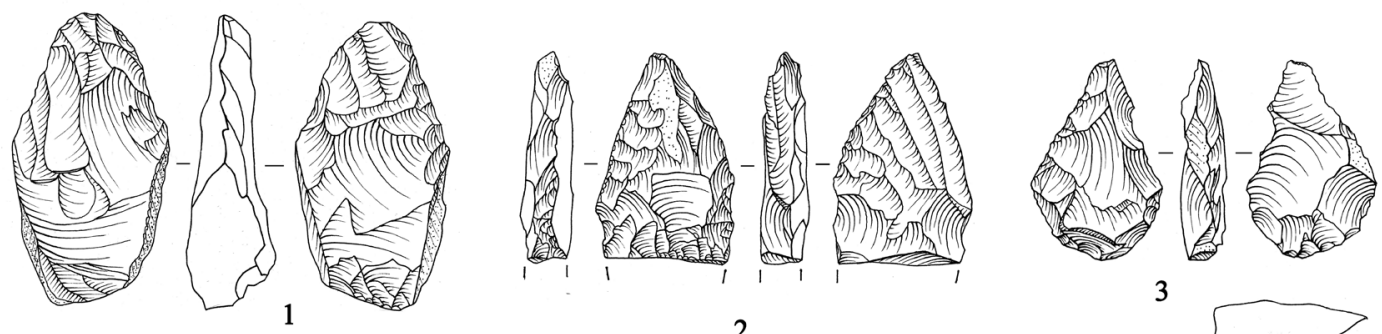

2
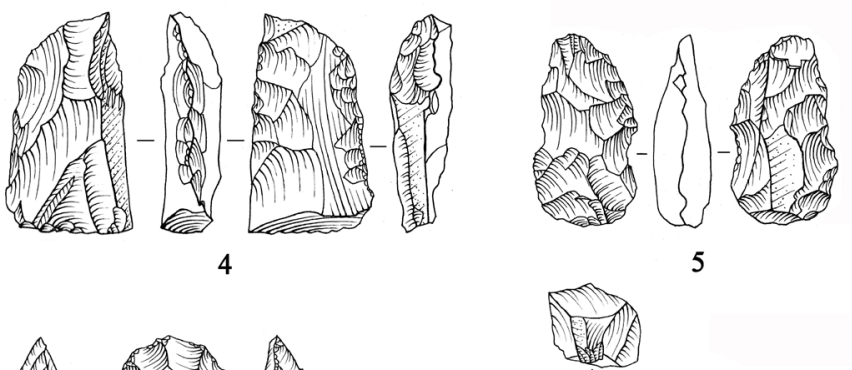

5

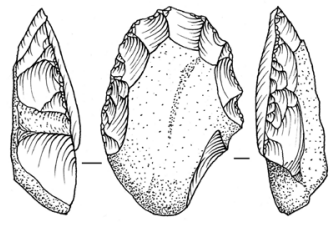

7

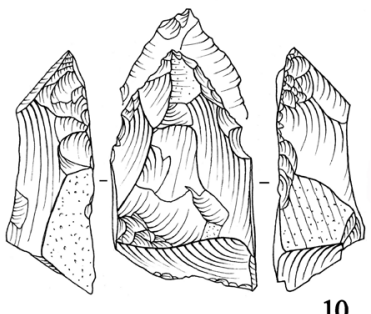

10
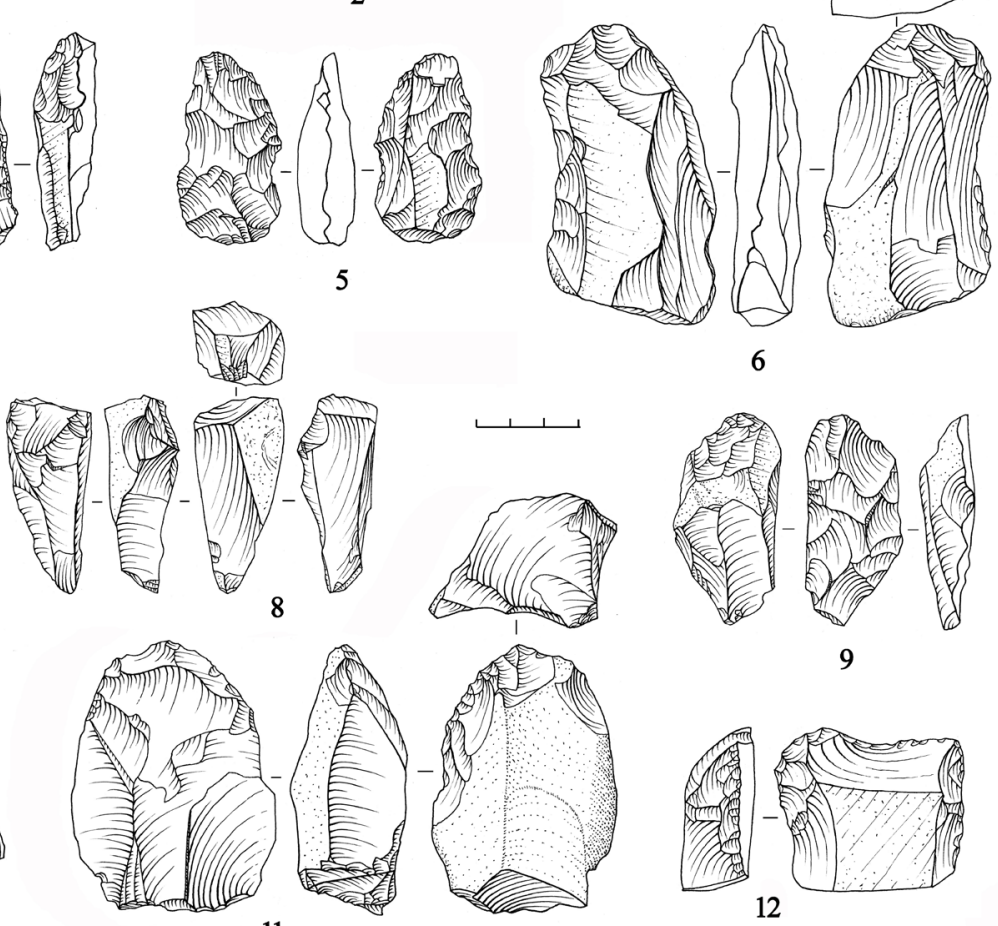

6

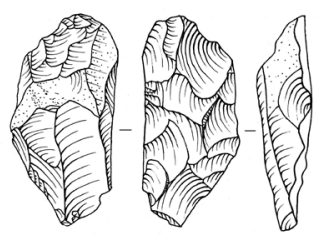

9

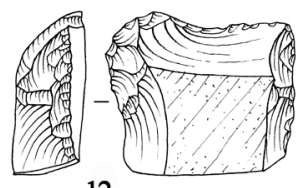

12
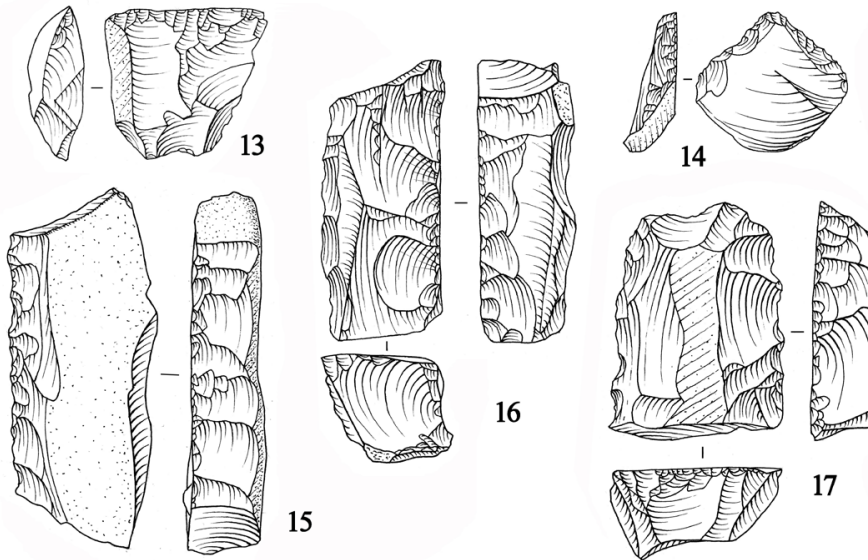

14
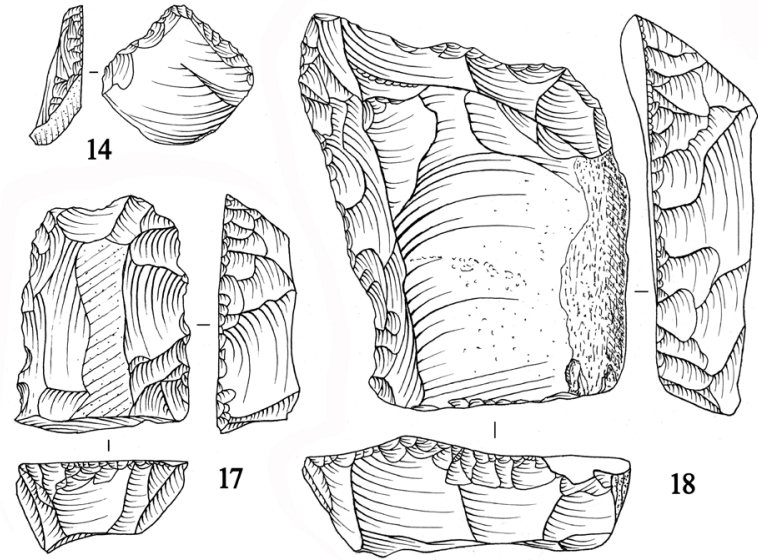

Puc. 5. Стоянка-мастерская Кусимово-6. Орудия: 1,3 - бифасы, 2 - наконечник копья, 4, 6, 9 ножи обушковые бифациальные, 5 - нож бифациальный, 7 - скребок концевой полукруглый на первичном сколе, 8 - скребок «с носиком», 10 - скребло конвергентное, 11 - полубифас, 12 скребок боковой, 13 - скребло поперечное прямое, 14 - скребок стрельчатый, 15, 16 - скребла, 17 - скребло двойное, прямое, 18 - скребло конвергентное прямое. Кремень. Автор: В. Г. Котов

[Fig. 5. Workshop site of Kusimovo-6. Tools: 1,3 - bifaces, 2 - spear point, 4, 6, 9 - backed knives, bifacial, 5 - knife, bifacial, 7 - end scraper, semicircular on the primary cleavage, 8 - end scraper 'with a nose', 10 - side scraper, convergent, 11 - partial biface, 12 - side scraper, 13 - side scraper, straight transverse, 14 - ogival end scraper, 15,16- side scrapers, 17 - side scraper, double straight, 18 - side scraper, convergent straight. Flint. Prep. by V. Kotov] 

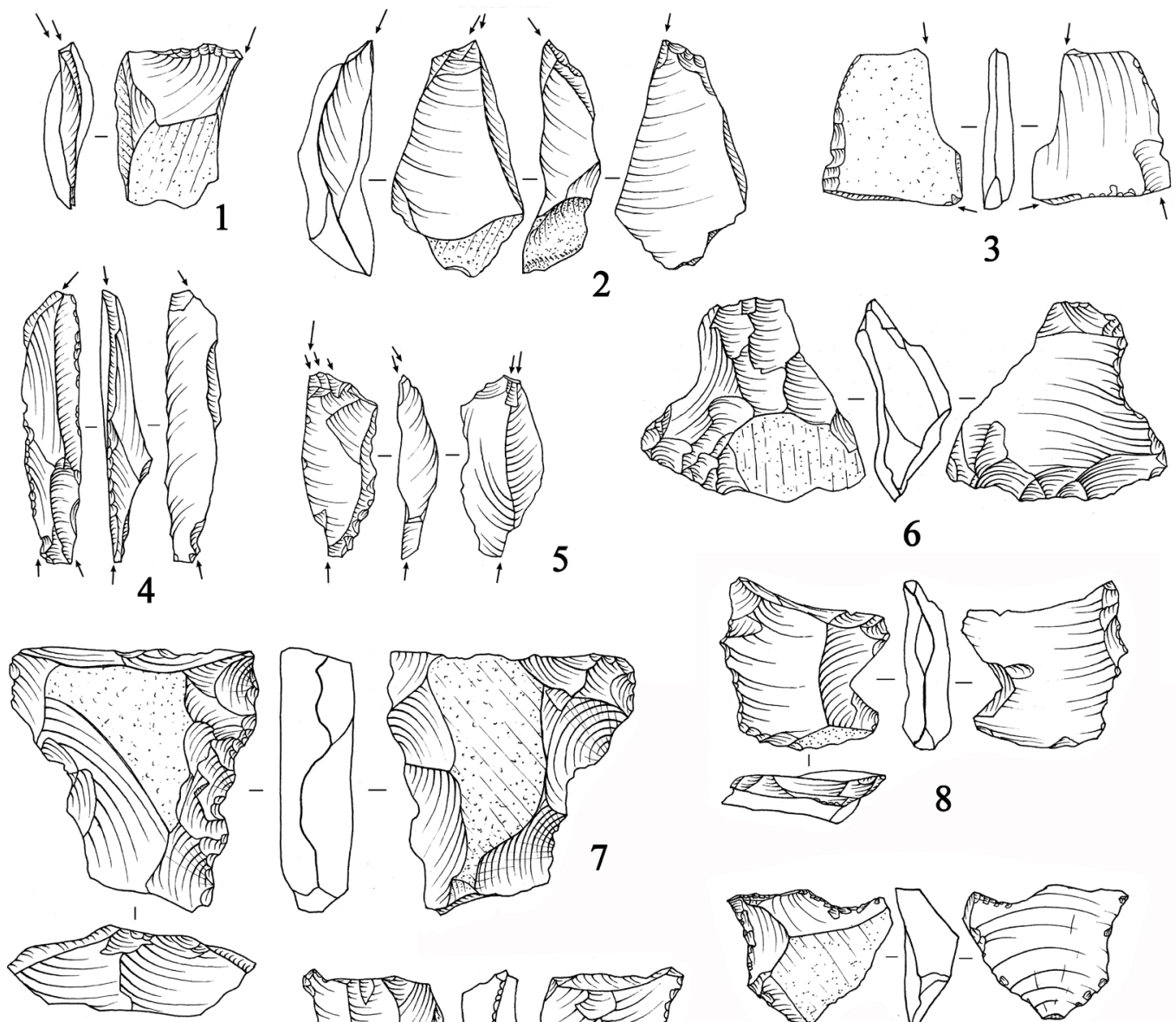

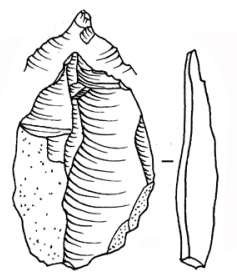

11
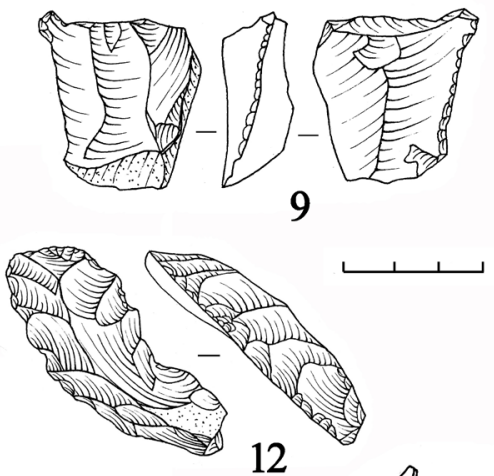

12
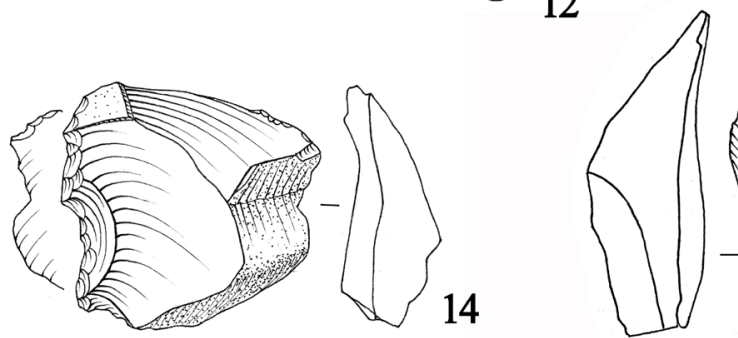
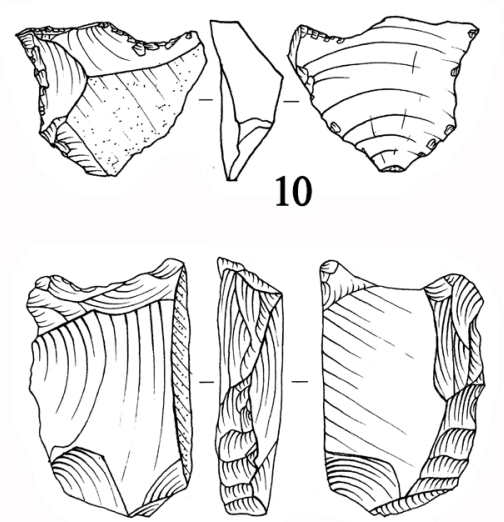

13
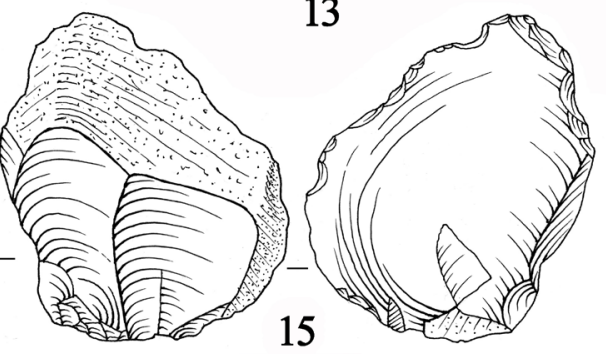

Рис. 6. Стоянка-мастерская Кусимово-6. Изделия: 1 - резец боковой ретушный, 2, 4 - резцы многофасеточные, 3 - резец тройной, 5 - резец латеральный, 6,7 - резчики бифациальные с черенком, 8,13 - клювовидные орудия, 9 - орудие с шипом, $10,12,14$ - выемчатые орудия, 11 проколка, 15 - зубчатое орудие. Кремень. Автор: В. Г. Котов

[Fig. 6. Workshop site of Kusimovo-6. Tools: 1 - burin, lateral retouching, 2, 4 - multifaceted burins, 3 — triple burin, 5- lateral burin, 6, 7- bifacial carvers with a shank, 8,13 - beak-shaped tools, 9 - tools with a thorn, 10,12,14- notched tools, 11 - punch, 15 - denticulate piece. Flint. Prep. by V. Kotov] 

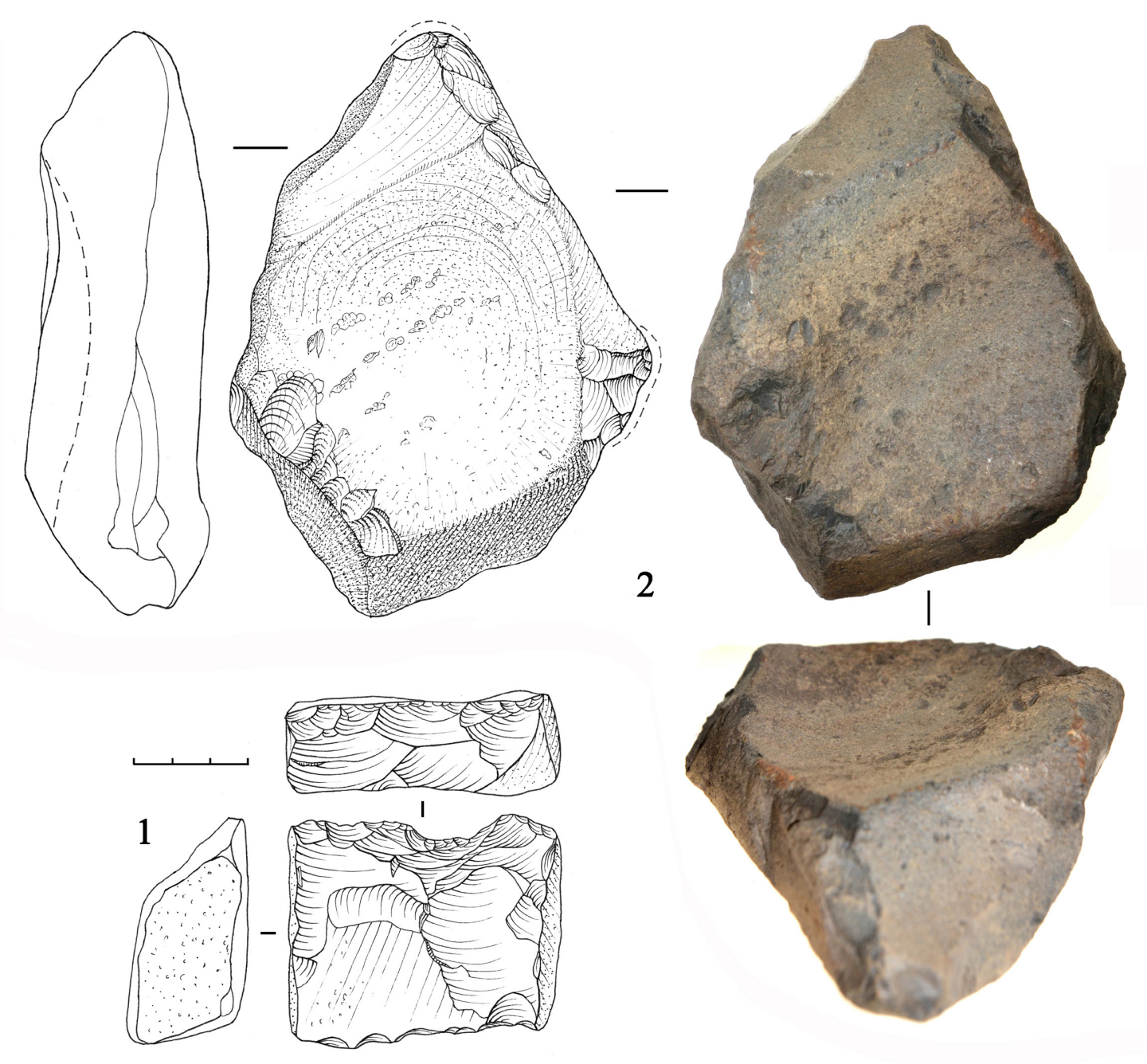

Puc. 7. Стоянка-мастерская Кусимово-6. Каменные изделия: 1 - чоппер на плитке из серого кремня; 2 - ступка-наковальня-отбойник на гальке из серого кремня. Автор: В. Г. Котов

[Fig. 7. Workshop site of Kusimovo-6. Stone products: 1 - chopper on a gray flint tile, 2 - mortar-anvilhammerstone on a pebble of gray flint. Author Prep. by V. Kotov] 
(рис. 5: 1), размер: 8,6х4,6×2,6 см; остроконечник бифациальный, ассиметричный, миндалевидной формы из черного кремня (рис. 5: 3), размер: 6х3,8х1,8 см; заготовка бифаса на гальке серого кремня, размер: $7 \times 4,2 \times 2,3$ см; остроконечник бифациальный подтреугольной формы из черного кремня (рис. 5: 3), размер: 6х4,2х1,4 см; заготовка бифаса, похожая на двусторонний нуклеус грубо радиального скалывания на плоской гальке темно-серого кремня, Размер: 9,5х5,5х2,5 см; полубифас-рубило на гальке серого кремня (рис. 5: 11), размер: $8 \times 6 \times 3,4$ см.

Весьма разнообразным является набор скребел, которых обнаружено 29 экз. Скребла представлены различными типами и подтипами: конвергентными (5 экз.) (рис. 5: 10, 18), простыми продольными (7 экз.) (рис. 5: 15, 16), поперечными (2 экз.) (рис. 5: 13), двойными (рис. 5: 17) и простыми (13 экз.). Все скребла были созданы в единой технике: рабочие грани формировались крутыми крупными сколами, затем выступы и грани выравнивались средними по величине сколами, и окончательно лезвие выравнивалось крутой несистематической ступенчатой ретушью, причем оно всегда было неровное в плане. Часть скребел имеет оформленные различными техническими приемами приостренные углы или концы. У одного массивного скребла двусторонним утончением создан черенок.

Другая родственная категория орудий - это скребки (17 экз.), которые также отличаются большим разнообразием. Среди этой категории выделены следующие типы: скребок боковой (рис. 5: 12), скребок прямой, скребок полукруглый (рис. 5: 7), скребок двойной, скребок стрельчатый (рис. 5: 14), скребок-резчик, скребок-нож, скребок-острие, микроскребок, скребок «с носиком» (рис. 5: 8).

Достаточно показательной во многих отношениях является такая категория, как ножи, всего было зафиксировано 13 экз. ( $2,7 \%$ от всех орудий). Все орудия типа ножей объединяет единая техника обработки и форма: поверхность изделий и рабочие участки с обеих сторон формировались крупными пологими сколами, лезвия выравнивались средними и мелкими сколами. У одних ножей лезвие завершается или закругленной режущей кромкой, или же острием (рис. 5: 4, 5, 6, 9). В целом эта техника не отличается от обработки других орудий с бифациальной обработкой и нуклеусов.

Другой категорией режущих инструментов являются резчики - 98 экз. (20\% от всех орудий). Это изделия, у которых рабочим участком выступала режущая кромка острия, шиповидного выступа или же угла. Обычно острие выделялось пологой или полукрутой ретушью с одной стороны какого-либо скола. Встречаются орудия с двумя рабочими кромками или с бифациальной ретушью. Было подмечено, что в качестве резчиков часто использовались укороченные массивные отщепы подтреугольных очертаний, концы которых подправлялись мелкой крутой ретушью. Два орудия, оформленные с применением бифациальной обработки, имеют черенки (рис. 6: 6,7).

Всего на памятнике установлено 47 экз. орудий с резцовым сколом, это 9,8\% от всех орудий. Большая часть резцов изготовлено на отщепах, и только единичные - на осколках. Среди резцов встречаются боковые ретушные (рис. 6: 1), боковые, латеральные (рис. 6: 5), срединные, многофасеточные (рис. 6: 2, 4), клювовидные, комбинированные (рис. 6: 3).

Еще одна функционально родственная предыдущим категория - это клювовидные орудия (4 экз.). У этих орудий клювовидный выступ был создан посредством ретуширования вогнутого или прямого края. У одного изделия имеются два клювовидных выступа, концы которых были обработаны ретушью (рис. 6: 8). Аналогичные изделия были встречены в тейякских материалах грота Бом Бон во Франции [Lumley et al. 1976: fig. 21, 9, 10].

Следующая достаточно многочисленная категория - это орудия с шипом - 53 экз. (11\% от всех орудий). Она во многом сходна с предыдущей по характеру обработки: посредством крутой противолежащей, односторонней или двусторонней (рис. 6: 9, 13) ретуши выделялся шиповидный выступ.

Точно так же оформлялись орудия с выделенным острием небольшого размера, которые были отнесены к проколкам (6 экз.). Посредством крутой ретуши оформлялись одна или две выемки, выделявшие острый выступ (рис. 6: 11). Встречаются экземпляры с выемками, оформленными противолежащей ретушью. 
Некоторым изделиям обработкой была придана остроконечная форма, поэтому они были отнесены к остриям - 21 экз. ( $2 \%$ орудий). Это могло быть достигнуто посредством ретуширования краев заготовки, ретушированием граней или же нуклевидной обработкой поверхности заготовок. Сходные острия присутствуют в тейяке Франции среди орудий в гроте Бом Бон [Lumley et al. 1976: fig. 21, 18-22].

К выемчатым орудиям были отнесены изделия с вогнутым ретушированным краем - 7 экз. В большинстве случаев это могут быть отщепы с ретушированными вогнутыми участками (рис. $6: 10,12,14$ ). К подобным орудиям были отнесены изделия с регулярной ретушью, чтобы исключить сколы, у которых выемки могли образоваться в результате повреждений естественного характера.

У ряда изделий форма образована крупными, глубокими сколами, и поверхность, а также край орудий не выравнивался более тщательной обработкой. Очевидно, это являлось одним из проявлений технологии этого населения. Все это дало основание выделить ряд изделий на отщепах, которые имели разнокалиберную ретушь по краям в качестве зубчатых орудий (4 экз.). В большинстве своем это отщепы с двусторонней ретушью и зубчатым краем (рис. 6: 15).

Рубящее орудие (чоппер) на плитке прямоугольной формы из темно-серого кремня (рис. 7: 1). Размер: 6х7,5х3 см. Несколькими крупными полукрутыми сколами было сформирована пологая грань и острый прямой край. Срединная часть рабочего лезвия имеет сильное повреждения в виде ступенчатой крупной полулунной ретуши с заломами, по краю тянется прерывистая чешуйчатая ретушь. Противоположная поверхность гладкая и ровная, сохраняет естественную корку. Боковые грани также естественные. Обушковая грань обработана по всей поверхности крупными отвесными сколами и дополнительно край выровнен средними сколами и мелкой атипичной ретушью.

В ходе раскопок была обнаружена крупная галька серого кремня подтреугольной формы с одной вогнутой поверхностью (рис. 7: 2). Основой для него послужила крупная плоская галька черного кремня размером $12,3 \times 16,7 \times 5$ см неправильной ромбо- видной формы. Одна сторона - выпуклая, представляет собой три продольные грани, причем средняя самая широкая и прямая. Это придает устойчивое положение данному предмету. На другой стороне посредством пикетажа и продолжительного абразивного воздействия каменным инструментом с абразивным действием образовалась выемка овальной формы до 13 мм глубиной и размером 9х10,5 см. Внутренняя поверхность заглажена, выровнена. Под микроскопом при 100-кратном увеличении видны участки сильной стертости и заполировки, а также разнонаправленные царапины. По краю видны участки с параллельными царапинами и бороздами. Очевидно, эти следы указывают на использование этого предмета в качестве ступки для перетирания мягковолокнистых материалов. На концах гальки и на одном краю изделия присутствуют негативы крупной ретуши с заломами, указывающие на употреблении предмета в качестве ударного инструмента для расщепления камня уже после появления выемки. Внутри выемки присутствуют цепочки звездчатой выкрошенности и неглубоких выщербин, концентрирующиеся по периферии углубления и отсутствующие в центре. В центре эти следы были сглажены в процессе работы абразивным инструментом. Это указывает на то, что данные выщерблины появились, очевидно, от ударов каменным предметом в процессе формирования углубления. По характеру обработки и следов использования этот предмет следует отнести к разряду комбинированных орудий, таких как ступка-отбойник. Характер повреждений от использования в качестве отбойника свидетельствует о том, что изделие следует относить к среднему палеолиту.

\section{Выводы}

Анализ коллекции со стоянки-мастерской Кусимово-6 показал ее гомогенность: все нуклеусы, сколы и орудия были изготовлены в рамках одной традиции. Расположение стоянки на выходах сырья предопределило характер коллекции: наличие и большое разнообразие нуклеусов, а также орудийных форм. В качестве сырья выступали гальки, а также слабо- или среднеокатанные куски фтанита. Изделия из яшмы красного, зеленого или же сургучно-зелено- 
го цветов единичны и составляют менее $1 \%$ от всех изделий. Отличительной чертой первичной обработки является полное отсутствие леваллуазских ядрищ. Нуклеусы представлены подпризматическими, подчетырехугольными плоскостными с продольным скалыванием, ортогональными, радиальными и бессистемными типами. Многие ядрища имеют две и больше плоскостей скалывания. Треть сколов обладают естественной ударной площадкой и спинкой. Индекс грубо фасетированных ударных площадок - 2,5\%. Тонко фасетированные площадки вообще единичны, что в совокупности с единичными атипичными леваллуазскими сколами указывает на нелеваллуазкий характер индустрии. Больше четверти всех сколов имеют удаленную (22 \%) или неопределимую $(4,5 \%)$ ударные площадки. Больше половины всех сколов (59 \%) имеют размер меньше 30 мм, около $20 \%$ - до 40 мм, до 50 мм - $12 \%$, и дальше в порядке уменьшения: до 60 мм - 4,2 \%, до 70 мм $2,6 \%$, остальные размеры представлены единичными экземплярами. Все это указывает на использование мелкоразмерного сырья и заготовок.

Обработка бифациальных орудий в основных чертах повторяет характер обработки нуклеусов. У всех бифациальных орудий присутствует сходная техника обработки и форма: поверхность изделий и рабочие участки формировались крупными пологими сколами, лезвия выравнивались средними и мелкими сколами. Складывается впечатление, что бифациальная обработка применялась так широко для компенсации недостатков заготовок.

Среди скребел преобладают простые, с выпуклыми лезвиями, реже встречаются с прямыми продольными и поперечными лезвиями, конвергентные и двойные. Скребки также отличаются разнообразием и неустойчивостью форм, причем некоторые трудно отличить от скребел. Достаточно многочисленны разнообразные угловые и остроконечные формы орудий с режуще-прокалывающими функциями: резцы, резчики, клювовидные орудия, острия, проколки. В коллекции присутствуют 3 орудия с черенком, у нескольких орудий были оформлены насады, что с вероятностью указывает на наличие составных инструментов.
Обращает на себя внимание отсутствие тщательности в отделке большинства орудий: поверхности и края орудий не выравнивались регулярной ретушью, часто лезвия в профиль и в плане неровные, ретушь имеет разную глубину и размеры, часто обрабатывались только рабочие участки. Не случайно по характеру краевой ретуши были выделены несколько изделий с зубчатым краем. Ряд орудий имеет обработку ретушью на вентрале, у некоторых рабочий участок образован на проксимальном участке.

Архаические черты в первичной и вторичной обработке сочетаются с наличием «прогрессивных» форм: резцов, скребков, проколок и пр. Они также отличаются разнообразием и неустойчивостью форм.

Bсе эти особенности характеризуют коллекцию как среднепалеолитическую с ашельскими традициями. Ашельские черты проявляются как в первичной обработке (наличие нуклеусов радиального, ортогонального, бессистемного скалывания, большое количество первичных сколов и сколов с радиальной, бессистемной огранкой), так и в присутствии таких архаических форм как рубила, бифациальные остроконечники, скребла прямые с отвесной ретушью, большое количество разнообразных бифациальных орудий (острия, резчики, ножи, резцы), зубчатые орудия. Данные особенности находят аналогии на южно-уральских памятниках с карышкинской индустрией, относящиеся к тейякской традиции раннего палеолита [Котов 2015]. Это сходство еще более усиливается в связи с наличием таких специфических типов орудий, как рубила с естественным обушком, скребла на плитках с прямым краем и отвесной ретушью, орудия с черенком, острия с бифациальной обработкой, орудия с шипом. Важно, что Тейякский индекс (Indice tayacien - IT) paвен 70, что сближает Кусимово-6 по этому индексу со слоем 2 пещеры Ля Микок (65$70 \%)$ и нижним слоем Ля Комбе (40-80 \%) во Франции [Любин 1965: 60].

Прямой аналогией таким сложным орудийным формам, как бифациальные остроконечники и рубильца со стоянки Кусимово-6, являются орудия, обнаруженные на стоянке в гроте Киик-Коба в Крыму и стоянке Ильская 1 на Северном Кавказе. В верхнем культурном слое грота Киик-Коба 
присутствуют бифациальные остроконечники плоско-выпуклой формы и рубильца [Бонч-Осмоловский 1940: табл. XI; XII, 1, 2 ; XVII, 1, 2]. Бифациальные остроконечники и конвергентные скребла из 3-го культурного слоя стоянки Ильская 1 внешне идентичны кусимовским изделиям [Щелинский, Кулаков 2005].

Определенное сходство в характере первичной обработки и типологическом наборе орудий есть со стоянкой им. Ч. Валиханова в горах Каратау в Южном Казахстане. Там также присутствует сочетание дисковидных и призматических нуклеусов, а среди орудий встречаются рубила, бифациальные остроконечники, конвергентные скребла, скребки высокой формы, разнообразные резцы, обушковые ножи. Отличительной особенностью стоянки им. Ч. Валиханова от других памятников является присутствие в коллекции бифациальных рубящих орудий дисковидной формы [Алпысбаев 1979: 158-176].

Наибольшее сходство стоянка-мастерская Кусимово-6 обнаруживает с III и IV слоями с тейякской индустрией среднего палеолита грота Старые Дуруиторы на северо-западе Молдовы [Анисюткин, Кетрару, Коваленко 2017]. Аналогии проявляются по многим линиям. Например, в нижнем IV культурном слое грота Старые Дуруиторы обнаружен большой процент сколов с галечной поверхностью, причем большая их часть имеют вторичную обработку или следы использования, что является характерной чертой тейякских индустрий [Анисюткин, Кетрару, Коваленко 2017: 64]. Точно так же находит аналогии и набор нуклеусов, среди которых представлены дисковидные, ашельские одноплощадочные, многогранные, пирамидальные, атипичные (бессистемные) формы. Отсутствуют в Кусимово-6 только шаровидные формы [Анисюткин, Кетрару, Коваленко 2017: 65-68, 87-89]. Достаточно многочисленные параллели мы находим орудийным формам молдавского памятника. Так, обработка рабочих участков скребел в гроте Старые Дуруиторы во многом повторяет орудия на стоянке-мастерской Кусимово-6: лезвия обработаны зубчатой, мелкой зубчатой, мелкой атипичной, крутой и грубой чешуйчатой ретушью, причем совершенно отсутствует обработка параллельной ретушью [Анисюткин, Кетра- ру, Коваленко 2017: 73]. В собрании орудий присутствуют сходные категории: скребки, резцы атипичные, проколки, ножи со спинкой, выемчатые орудия, зубчатые орудия, резцевидные острия (резчики), отщепы с ретушью со стороны брюшка, клювовидные орудия-резчики, клювовидные острия, долотовидные орудия, скребки на ударных площадках отщепов, бифасы [Анисюткин, Кетрару, Коваленко 2017: 71-83, 91-96]. Различается лишь процентное соотношение этих орудий. Вместе с тем в гроте Старые Дуруиторы присутствуют чопперы, тейякские остроконечники, острия «с плечиками», которые не были зафиксированы или представлены единичными экземплярами на стоянке-мастерской Кусимово-6, хотя эти формы немногочисленны и на тейякских памятниках Молдовы [Анисюткин, Кетрару, Коваленко 2017: 79]. Наряду с этим, в индустрии стоянки-мастерской Кусимово-6 присутствует ряд своеобразных черт, отличающих ее от других памятников: обработка бифасов параллельными удлиненными снятиями, имеются в наличии треугольные бифациальные острия укороченных очертаний, скребла простые прямые с отвесной ретушью, скребки стрельчатые, обушковые бифациальные ножи, резчики с бифациальной обработкой и черенком, бифациальные острия, более серийно выражены резцы. Все это указывает на какую-то общую древнюю индустриальную основу обеих традиций, что не исключают возможность контактов и на горизонтальном временном уровне. Обилие клювовидных форм может указывать на сохранение в течение долгого времени нижнепалеолитических традиций, своим происхождением связанных с центрально-европейским клектоном [Анисюткин 1973: 234].

Тем не менее массив аналогий указывает на одновременность двух традиций и обоих памятников. Так культурные слои IV и III грота Старые Дуруиторы по совокупности различных данных датируются первой половиной рисского времени (300-200 тыс. лет назад) [Анисюткин, Кетрару, Коваленко 2017: 62], в таком случае и стоянка-мастерская Кусимово-6 должна относиться к рисскому периоду. Точно так же тейякские материалы во Франции датируются рисским временем [Lumley et al. 1976: 845]. Памятники тейякской традиции в мире чрезвычайно редки и даже само выделение подобной 
индустрии до настоящего времени является дискуссионным [Вишняцкий 2011]. Открытие нового тейякского памятника среднего палеолита с многочисленной и разнообраз- ной коллекцией изделий из кремня на Южном Урале даст возможность лучше понять историю заселения региона и взаимодействие с населением других регионов.

Таблица 1. Находки со стоянки-мастерской Кусимово-6. Раскопки 2019 г.

[Table 1. Finds from workshop site of Kusimovo-6. Excavations of 2019]

\begin{tabular}{|c|c|c|c|c|c|c|}
\hline № & Название изделия & Сектор 1 & Сектор 2 & Сектор 3 & Сектор 4 & Итого \\
\hline 1. & Отщеп & 526 & 178 & 116 & 94 & 914 \\
\hline 2. & Отщеп с ретушью & 222 & 134 & 86 & 63 & 505 \\
\hline 3. & Осколок & 28 & 3 & - & 1 & 32 \\
\hline 4. & Осколок с ретушью & 3 & 4 & 2 & - & 9 \\
\hline 5. & $\begin{array}{l}\text { Пластина аморфная с } \\
\text { ретушью }\end{array}$ & 1 & - & - & 2 & 3 \\
\hline 6. & Плитка с ретушью & 1 & - & - & 1 & 2 \\
\hline 7. & Пластина аморфная & 1 & 1 & 1 & - & 3 \\
\hline 8. & Отщеп пластинчатый & 11 & 2 & 3 & 5 & 21 \\
\hline 9. & $\begin{array}{l}\text { Отщеп пластинчатый с } \\
\text { ретушью }\end{array}$ & 3 & - & - & 1 & 4 \\
\hline 10. & $\begin{array}{l}\text { Отщеп пластинчатый } \\
\text { усеченный с ретушью }\end{array}$ & 1 & - & - & - & 1 \\
\hline 11. & Отщеп леваллуа & - & - & 1 & 1 & 2 \\
\hline 12. & Отщеп с острием & 2 & - & - & - & 2 \\
\hline 13. & Отщеп с подтеской & - & 1 & - & - & 1 \\
\hline 14. & Галька с ретушью & 1 & - & - & - & 1 \\
\hline 15. & Отщеп с подтеской & 4 & - & 1 & - & 5 \\
\hline 16. & Расколотая галька & 7 & - & - & 3 & 10 \\
\hline 17. & Чешуйки & 3 & - & - & - & 3 \\
\hline 18. & Пренуклеус & - & - & 1 & - & 1 \\
\hline 19. & Нуклеус бессистемный & 12 & 8 & 11 & 10 & 41 \\
\hline 20. & Нуклеус аморфный & 24 & 4 & 10 & 5 & 43 \\
\hline 21. & Нуклеус продольный & & 1 & 2 & 2 & 5 \\
\hline 22. & Нуклеус двусторонний & - & 1 & - & - & 1 \\
\hline 23. & Нуклевидное изделие & 63 & 23 & 14 & 16 & 116 \\
\hline 24. & $\begin{array}{l}\text { Нуклеус } \\
\text { многоплощадочный }\end{array}$ & 1 & - & - & - & 1 \\
\hline 25. & Нуклеус ортогональный & 2 & 1 & 5 & 7 & 15 \\
\hline 26. & $\begin{array}{l}\text { Нуклеус перекрестного } \\
\text { скалывания }\end{array}$ & 2 & 1 & - & - & 3 \\
\hline 27. & Нуклеус радиальный & 4 & 4 & - & 2 & 10 \\
\hline 28. & $\begin{array}{l}\text { Нуклеус уплощенный } \\
\text { одноплощадочный }\end{array}$ & 1 & - & - & 2 & 3 \\
\hline 29. & Нуклеус с ретушью & - & 1 & - & - & 1 \\
\hline 30. & Скол нуклевидный & 6 & 1 & - & - & 7 \\
\hline 31. & $\begin{array}{l}\text { Нуклевидное изделие - } \\
\text { скребло }\end{array}$ & 8 & 1 & - & - & 9 \\
\hline 32. & $\begin{array}{l}\text { Нуклевидное изделие с } \\
\text { ретушью }\end{array}$ & 1 & 2 & 1 & & 4 \\
\hline 33. & $\begin{array}{l}\text { Нуклевидное изделие- } \\
\text { отбойник }\end{array}$ & - & 2 & - & - & 2 \\
\hline 34. & Отбойник на гальке & 33 & 10 & 12 & 18 & 73 \\
\hline
\end{tabular}


Oriental Studies. 2020. Vol. 13. Iss. 6

\begin{tabular}{|c|c|c|c|c|c|c|}
\hline 35. & Отбойник на плитке & 4 & & 1 & 1 & 6 \\
\hline 36. & Отбойник на куске кремня & 1 & 2 & 3 & 3 & 9 \\
\hline 37. & Отбойник на сколе & - & - & - & 1 & 1 \\
\hline 38. & $\begin{array}{l}\text { Остроконечник } \\
\text { бифациальный }\end{array}$ & - & 1 & - & - & 1 \\
\hline 39. & Молоток-отбойник & 1 & 1 & - & 2 & 4 \\
\hline 40. & Ретушер & 5 & 8 & 3 & 5 & 21 \\
\hline 41. & Ретушер-отбойник & - & 2 & - & - & 2 \\
\hline 42. & Ретушер-отжимник & - & 1 & - & - & 1 \\
\hline 43. & Клювовидное орудие & - & 1 & 3 & - & 4 \\
\hline 44. & Резчик & 40 & 27 & 16 & 8 & 91 \\
\hline 45. & Резчик-острие & 2 & - & - & - & 2 \\
\hline 46. & Резчик с черенком & - & 1 & - & - & 1 \\
\hline 47. & Резец-резчик & 3 & 1 & - & - & 4 \\
\hline 48. & Резец & 18 & 11 & 11 & 6 & 46 \\
\hline 49. & Резец тройной & - & 1 & - & - & 1 \\
\hline 50. & Резец-нож & - & - & 1 & - & 1 \\
\hline 51. & Рубило & - & 1 & - & - & 1 \\
\hline 52. & Микрорезчик & 1 & - & - & - & 1 \\
\hline 53. & Орудие с шипом & 25 & 12 & 15 & 1 & 53 \\
\hline 54. & Орудие с шипом-резец & - & 1 & - & - & 1 \\
\hline 55. & $\begin{array}{l}\text { Рубящее орудие } \\
\text { двустороннее }\end{array}$ & - & - & 1 & 2 & 3 \\
\hline 56. & $\begin{array}{l}\text { Рубящее орудие-скребок на } \\
\text { нуклеусе }\end{array}$ & 1 & - & - & - & 1 \\
\hline 57. & Скребло & 7 & 2 & 4 & - & 13 \\
\hline 58. & Скребло продольное & - & - & 1 & 6 & 7 \\
\hline 59. & Скребло поперечное & 2 & - & - & - & 2 \\
\hline 60. & Скребло конвергентное & 2 & - & 1 & 2 & 5 \\
\hline 61. & Скребло скошенное & - & - & 1 & - & 1 \\
\hline 62. & Скребло двойное & - & - & 1 & - & 1 \\
\hline 63. & Скребок & 1 & 1 & - & - & 2 \\
\hline 64. & Скребок боковой & 1 & - & - & - & 1 \\
\hline 65. & Скребок прямой & 1 & - & - & - & 1 \\
\hline 66. & Скребок двойной & 1 & - & - & - & 1 \\
\hline 67. & Скребок-резчик & 1 & - & - & - & 1 \\
\hline 68. & Скребок-острие & 1 & - & 1 & - & 2 \\
\hline 69. & Микроскребок & - & 1 & - & - & 1 \\
\hline 70. & Наконечник копья & 1 & - & - & - & 1 \\
\hline 71. & Скребло на нуклеусе & 1 & - & - & - & 1 \\
\hline 72. & Скребло-скобель & 1 & - & - & - & 1 \\
\hline 73. & Скребло-резчик & 1 & - & - & - & 1 \\
\hline 74. & $\begin{array}{l}\text { Острие с частично } \\
\text { бифациальной обработкой }\end{array}$ & 1 & - & - & - & 1 \\
\hline 75. & $\begin{array}{l}\text { Острие с противолежащей } \\
\text { ретушью }\end{array}$ & - & 1 & - & - & 1 \\
\hline 76. & Острие & 8 & 6 & 3 & 4 & 21 \\
\hline 77. & Нож обушковый & 2 & 7 & 4 & & 13 \\
\hline 78. & Проколка & 2 & 2 & 2 & & 6 \\
\hline 79. & Орудие с шипом-резчик & 1 & - & - & - & 1 \\
\hline 80. & $\begin{array}{l}\text { Нуклевидное изделие- } \\
\text { резчик }\end{array}$ & 1 & - & - & - & 1 \\
\hline 81. & Выемчатое орудие & 1 & 3 & 2 & 1 & 7 \\
\hline
\end{tabular}




\begin{tabular}{|c|l|c|c|c|c|c|}
\hline 82. & $\begin{array}{l}\text { Орудие с двусторонней } \\
\text { обработкой }\end{array}$ & 1 & - & 1 & - & 2 \\
\hline 83. & Зубчатое орудие & 1 & 1 & - & - & 2 \\
\hline 84. & Кливер & 1 & - & - & - & 1 \\
\hline 85. & Комбинированное орудие & - & - & - & 2 & 2 \\
\hline & Итого & 1115 & 478 & 351 & 275 & 2219 \\
\hline
\end{tabular}

\section{Источники}

Котов 2008 - Котов В. Г. Научный отчет об археологической разведке в Абзезиловском районе Республики Башкортостан в 2005 г. Уфа, 2008 // Личный архив автора.

Русланова 2020 - Русланова Р. Р. Научный отчет о начале археологических раскопок кургана № 1 курганного могильника Кусимово-3 и участка стоянки Кусимово-6 в Абзелиловском районе Республики Башкортостан по Открытому листу № 1589-2019 от 29.07.2019 г.: в 2 тт. Уфа, 2020 // Личный архив автора.

\section{Литература}

Алпысбаев 1979 - Алпысбаев Х. А. Памятники нижнего палеолита Южного Казахстана (О древнейшем заселении Казахстана первобытным человеком). Алта-Ата: Наука КазССР, 1979. 208 с.

Анисюткин 1973 - Анисюткин Н. К. Орудия клювовидных форм в раннем и среднем палеолите // Советская археология. 1973. № 1. С. 228-234.

Анисюткин, Кетрару, Коваленко 2017 Анисюткин Н. К., Кетрару Н. А., Коваленко С. И. Многослойная палеолитическая стоянка в гроте Старые Дуруиторы и место ее каменных индустрий в раннем и среднем палеолите Европы. СПб.: Нестор-История, 2017. $200 \mathrm{c}$.

Бонч-Осмоловский 1940 - Бонч-Осмоловский Г. А. Грот Киик-Коба. Палеолит Крыма. Вып. 1. М.; Л.: Изд-во АН СССР, 1940. 226 c.

Вишняцкий 2011 - Вишняцукий Л. Б. Тейяк почти не виден // Российский археологический ежегодник. 2011. № 1. С. 657-660.

Казаков 2017 - Казаков П. В. Остаточные озеpa N-Q палеогидросети, озерные комплексы и сопутствующие им полезные ископаемые (восточный склон Южного Урала и Зауралье) // Геология. Известия Отделения наук о Земле и природных ресурсов Академии наук Республики Башкортостан. 2017. № 23.

\section{Sources}

Kotov V. G. 2005 Archaeological Reconnaissance in Abzelilovsky District of Bashkortostan (Russia): Scientific Report. Ufa, 2008. At: Author's Personal Archives. (In Russ.)

Ruslanova R. R. Initial Archaeological Excavations of Kurgan 1 at the Burial Mound Site of Kusimovo-3 and Those of a Section of Kusimovo-6 Site in Abzelilovsky District of Bashkortostan (Russia), Permit No. 1589-2019 of 29 July 2019: Scientific Report. In 2 vols. Ufa, 2020. At: Author's Personal Archives. (In Russ.)

C. $63-68$.

Казаков 2018 - Казаков П. В. К перспективам изучения озерной котловины озера Сагылкуль в Южном Зауралье // Геология, полезные ископаемые и проблемы геоэкологии Башкортостана: XII Межрегион. науч.-практич. конф. (Уфа, 21-23 мая 2018 г. / отв. ред. В. Н. Пучков. Уфа: Институт геологии УНЦ PAH, 2018. C. 339-341.

Котов 2009 - Котов В. Г. Палеолит // История башкирского народа. Т. 1 / отв. ред. М. М. Кульшарипов. М.: Наука, 2009. С. 2353.

Котов 2015 - Котов В. Г. Стоянка-мастерская Карышкино-11 - новый памятник нижнего палеолита Южного Урала // Вестник Пермского университета. 2015. № 1. С. 7-20.

Любин 1965 - Любин В. П. К вопросу о методике изучения нижнепалеолитических каменных орудий // Палеолит и неолит СССР. Т. 5. (Материалы и исследования по археологии СССР). № 131. М.; Л.: Наука, 1965. С. 7-75.

Мосин, Никольский 2008 - Мосин В. С., Никольский $B$. Ю. Кремень и яшма в материальной культуре населения каменного века Южного Урала. Екатеринбург: УрО РАН, 2008. $196 \mathrm{c}$.

Щелинский, Кулаков 2005 - Щелинский B. E., Кулаков С. А. Ильская мустьерская стоянка (раскопки 1920-х - 1930-х годов). СПб.: Европейский Дом, 2005. 96 с. 
Lumley et al. 1976 - Lumley H., CollinaGirard J., Abelanet J., Bazile F., Meignen L. Les premmières industries humaines en

Lumley H. (dir.). Editions du Centre National de la Recerche scientifique, 1976. Pp. 777-794.

\section{References}

Alpysbaev Kh. A. Lower Paleolithic Monuments of Southern Kazakhstan: Earliest Traces of Man in Present-Day Kazakhstan. Alta-Ata: Nauka (KazSSR), 1979. 208 p. (In Russ.)

Anisyutkin N. K. Beak-shaped tolls in the Early and Middle Paleolithic. Sovetskaya arkheologiya. 1973. No. 1. Pp. 228-234. (In Russ.)

Anisyutkin N. K., Ketraru N. A., Kovalenko S. I. Multilayered Paleolithic Site in Starye Duruitory Grotto, and Impact of Its Stone Industries in Europe's Early and Middle Paleolithic. St. Petersburg: Nestor-Istoriya, 2017. 200 p. (In Russ.)

Bonch-Osmolovsky G. A. Paleolithic in the Crimea: Kiik-Koba Grotto. Vol. 1. Moscow; Leningrad: USSR Academy of Sciences, 1940. 226 p. (In Russ.)

Kazakov P. V. Basin of Proto-Lake Sagylkul in the Southern Transurals: research prospects revisited. In: Puchkov V. N. (ed.) Bashkortostan. Geology, Fossil Minerals and Issues of GeoEcology. Conference Proceedings (Ufa; May 21-23, 2018). Ufa, 2018. Pp. 339-341. (In Russ.)

Kazakov P. V.Relict lakes of N-Q paleohydrosystem, lake clusters and related fossil minerals (east of the Southern Urals and Transurals). Geologiya. Izvestiya Otdeleniya nauk o Zemle i prirodnykh resursov Akademii nauk Respubliki Bashkortostan. 2017. No. 23. Pp. 63-68. (In Russ.)

Kotov V. G. Paleolithic. In: Kulsharipov M. M.
Languedoc méditerranéen et en Roussillon // La Préhistoire Française. Tome1. Les civilizations Paléolithiques et Mésolithiques de la France /

(ed.) A History of the Bashkir People. Vol. 1. Moscow: Nauka, 2009. Pp. 23-53. (In Russ.)

Kotov V. G. Workshop site of Karyshkino-11 a new Lower Paleolithic monument in the Southern Urals. Perm University Herald. 2015. No. 1. Pp. 7-20. (In Russ.)

Lumley H., Collina-Girard J., Abelanet J., Bazile F., Meignen L. Les premmières industries humaines en Languedoc méditerranéen et en Roussillon (Earliest industries in the Mediterranean Languedoc- Roussillon). In: Lumley H. (dir.) La Préhistoire Française (Prehistory of France). Vol. 1: Les civilizations Paléolithiques et Mésolithiques de la France (Paleolithic and Mesolithic in France). French National Centre for Scientific Research, 1976. Pp. 777-794. (In Fr.)

Lyubin V. P. Lower Paleolithic stone tools: research methods revisited. In: Paleolithic and Neolithic in the USSR. Vol. 5. (Ser.: Materials and Studies in the Archaeology of the USSR. No. 131.) Moscow; Leningrad: Nauka, 1965. Pp. 7-75. (In Russ.)

Mosin V. S., Nikolsky V. Yu. Stone Age in the Southern Urals: Flint and Gem Jade in Material Culture of Indigenous Population. Yekaterinburg: Ural Branch of RAS, 2008. 196 p. (In Russ.)

Shchelinsky V. E., Kulakov S. A. Excavating the Mousterian Site of Ilskaya, 1920s-1930s. St. Petersburg: Evropeyskiy Dom, 2005. 96 p. (In Russ.)

Vishnyatsky L. B. The almost unseen Tayacian. Russian Archaeological Yearbook. 2011. No. 1. Pp. 657-660. (In Russ.) 